\title{
Overview of genetically modified crops and their relevance for Nicaragua
}

\author{
Marisser H. Álvarez-Guevara, Luvianca G. Gil-Moreno, Julio A. Gó- \\ mez-Rodríguez and Jorge A. Huete-Pérez
}

Recibido: octubre 2012/ Aceptado: noviembre 2012

The first transgenic plants were created in Europe about three decades ago. In Nicaragua, however, there is not commercial cultivation of transgenic crops allowed yet, and the only history of transgenic grain imports occurred in 2005, when the introduction of 15 events of GM maize was first authorized. The Law on Prevention of Risks from Living Modified Organisms by Means of Molecular Biotechnology was published in 2010, and more recently, in September 2012, the Law on Conservation and Sustainable Use of Biodiversity came into force. In line with the resulting requirements from these laws, the Ministry of Agriculture and Forestry (MAGFOR) currently works in coordination with the Molecular Biology Center at the University of Central America to ensure that grains imported in the country correspond to events legally authorized. This article begins by presenting an overview of transgenic crops (GMO), their history and their implications for the economy and human health. Next, we describe the current status of GMO in Nicaragua. We conclude that MAGFOR has been successful in fulfilling the law in regards to sampling of imports related to the introduction of GMO grains. It is recommended, however, that for better monitoring of compliance with these laws, it will be necessary to establish a systematic monitoring plan nationwide, aimed at the appropriate screening and detection of transgenic material both in crop seeds as well as in imported grains.

Keywords: biosafety, GMO detection, regulation.

Molecular Biology Center, University of Central America, UCA. Managua. Nicaragua.

Email:cbm_uca@ns.uca.edu.ni 


\section{Introduction}

Genetically Modified Organisms (GMO) are crops or animals in which the genetic material (DNA) has been altered in a way to introduce genes from another organism or species using modern molecular biology techniques. The technology is often called "genetic engineering" or "gene technology". It allows selected individual genes to be transferred from one organism into another, including also the transfer between non-related species. This is done to provide new properties and characteristics to the recipient elements of the genes which are natural in the donor element (Bolívar Zapata, 2011).

The introduction of GMO in agriculture is the latest step in agronomic selection since humans began farming. For numerous thousand years farmers have been changing the genetic composition of the crops they cultivate. Human selection for a number of characteristics such as faster growth, food textures, seed diversity or sweeter fruits has radically modified cultivated plants compared to their wild native species. Amazingly, many of our current crops were developed by trial and error by simple people without any scientific training on plant breeding (UNESCO, 2000).

The first transgenic plants took place in 1983, and tobacco was the first plant used for this method, achieving its resistance to antibiotics. Professor Marc Van Montagu produced tobacco plants that were resistant to kanamycin and to methotrexate in his laboratory in Belgium. Tomato was the second plant, acquiring also resistance to insects. Before these achievements, transgenesis had been successful in microorganisms in 1973, and in 1982, the first transgenic rat was created, becoming the first animal of this type (UNESCO, 2000).

The creation of the GM tobacco plants generated an explosion of research leading to the development of crops with commercially valuable traits. Initially the trend was to focus on single-gene properties such as herbicide resistance. In this method crops were able to prosper when dowsed with herbicides that killed the weeds around them. Another property introduced into crops was pest resistance, with crops carrying a gene that made them toxic to insects that attacked them. Through this strategy the need to spray entire fields with chemicals was eliminated. Three decades after the transformation events in plants, thanks to genetic engineering technology human understanding of the molecular basis of plant growth and development, stress tolerance, flowering, and ecological adaptation has dramatically improved (UNESCO, 2000).

It is important to bear in mind that the anthropic activities (deforestation, rural development) in less than 50 years have transformed and exploited their ecosystems in such a way that they had never been done before to satisfy food demands, fresh water, fuel, and clothes of the fast growing world population. The most traumatic consequences caused by climate change prompted by man are the increase of temperature and the reduction of the amount of rainfall, especially in those regions where food security is a serious problem (PNUMA, 2005).

One of the main global challenges of the twenty first century is to increase the productivity of harvest through an increase in efficiency and efficacy patterns in the production process, adding value to the production with no environmental 
degradation, all of which may be achieved by genetic improvement of crops (Chrispeels, M.J \& Sadava, D.E, 2003). Scientists have identified, for instances, many types of genes which have given some plants some kind of resistance when there is water deficit due to severe droughts caused by climate change. Some of these genes could be used in plants which could resist water deficit by complying with the effective use of water through the fulfillment of three principles: (1) catching as much water as possible, (2) use of water caught effectively in plant growth, and (3) directing the photosynthesis process in the field (Chrispeels, M.J \& Sadava, D.E, 2003).

\section{Economic impact of GMO}

Genetic improvement in seeds through modern molecular biology techniques has been carried out mainly by a reduced number of international companies to give these products some characteristics that farmers would take as significantly beneficial for their work and economy because they contain a clearly marked increase in the protection from diseases transmitted by insects, viruses, or because they are more tolerant to herbicides. Some of these companies are: Monsanto, Aventis (Bayer), Syngenta (Novartis and AstraZeneca), DowAgrosciences, DuPont (UNESCO, 2000; Santamarta, 2004). General Information about these companies is presented in Table 1.

Table 1. Top GMO seeds companies.

\begin{tabular}{|l|l|l|l|l|}
\hline Company & $\begin{array}{l}\text { Country of } \\
\text { Origin }\end{array}$ & Market Segment & Main products & $\begin{array}{c}\text { Investment } \\
\text { 2011 (US\$ } \\
\text { million) }\end{array}$ \\
\hline Monsanto & USA & $\begin{array}{l}\text { Agricultural } \\
\text { productivity } \\
\text { (Research, trade } \\
\text { of herbicides, } \\
\text { and other } \\
\text { protection crop } \\
\text { products, etc.) and } \\
\text { transgenic products } \\
\text { (biotechnological } \\
\text { research and trade } \\
\text { of seeds) }\end{array}$ & $\begin{array}{l}\text { Gard Plus, Yield } \\
\text { Gard Rootworm, } \\
\text { Yield Gard } \\
\text { Corn Borer } \\
\text { and Roundup } \\
\text { Ready Corn } \\
\text { 2. In addition, } \\
\text { transgenic } \\
\text { soybean } \\
\text { Roundup Ready } \\
\text { Soybeans }\end{array}$ & 1,386 \\
\hline $\begin{array}{l}\text { Aventis } \\
\text { (Bayer) }\end{array}$ & $\begin{array}{l}\text { Gharmaceutical } \\
\text { products, nutrition, } \\
\text { production of } \\
\text { transgenic products, } \\
\text { pesticides, and other } \\
\text { products supporting } \\
\text { agro industry. }\end{array}$ & $\begin{array}{l}\text { Liberty Link } \\
\text { (LL) 602 }\end{array}$ & 2,932 \\
\hline
\end{tabular}




\begin{tabular}{|l|l|l|l|l|}
\hline Syngenta & Switzerland & $\begin{array}{l}\text { Research, } \\
\text { development, and } \\
\text { trade of herbicides, } \\
\text { herbicides, } \\
\text { insecticides, } \\
\text { fungicides } \\
\text { pesticides, and } \\
\text { transgenic products. }\end{array}$ & $\begin{array}{l}\text { Corn Bt (Bacillus } \\
\text { Thuringiensis) }\end{array}$ & 1,127 \\
\hline $\begin{array}{l}\text { Dow } \\
\text { Agrosciencies }\end{array}$ & USA & $\begin{array}{l}\text { Development and } \\
\text { trade of chemical } \\
\text { and transgenic } \\
\text { products. }\end{array}$ & Mycogen seeds & 1,646 \\
\hline Dupont & USA & $\begin{array}{l}\text { Construction, } \\
\text { electronics, Textile } \\
\text { Industry, and agro } \\
\text { industry. }\end{array}$ & $\begin{array}{l}\text { Soybean and } \\
\text { corn. }\end{array}$ & 1,240 \\
\hline
\end{tabular}

Source:

Generally speaking, to develop the transgenic organisms, these companies are to comply with five main stages: first the conceptualization of the product, and its desired characterization, arising from a real need in a specific region. Later, they search for the genes required in literature and bioassays. The next step is the selection of the events: first in greenhouses that are taken to field tests in small patches. This aims at choosing the best event in accordance with the criteria set in the first stage. The next stage concerns regulation studies which aim at completing the biosafety evaluation of potential commercial releases. These include an agronomic equivalence, an expression and composition analysis, non-objective organism studies in crop conditions, additionally to those conducted in laboratories. Furthermore, they include sub-chronic and nutritional toxicity studies (Zampierin, s.f.). Specifically, the plant transgenesis process considered in the second stage comprises certain stages: the extraction of the gene that expresses the desired characteristic from donor organism; the gene of interest is obtained; production of genetic constructs; induction of genes in the host cells through direct transfer by particle bombardment or by a biological vector; finally, the regeneration of the whole organism after modification (UNESCO, 2000).

The whole process to generate a transgenic crop usually takes between 10 and 15 years for their implementation, with an investment of about US\$ 100 million dollars (Ortiz, 2010). The transgenic production that has been carried out by the different companies is seen as a great commercial availability of these crops, taking into account that $23 \%$ of the world corn harvest comes from transgenic plants and $61 \%$ of all transgenic crops in the world is comprised of soybean (Santamarta, 2004).

In addition, this technological innovation has had an economic impact on farmers, consumers, and the rest of society. Such impacts depend to a large extent on the effects of employed techniques in agronomy and on the outputs, acceptance of consumers, regulation requirements, and corresponding costs. Therefore, the 
economic net effect of the transgenic crops varies depending on the country and its development dynamics (FAO, 2001). In China, on the other hand, genetic engineering is being considered as a possible way of boosting China's food security, and to lessen the effects of industrialization, which reduces the availability of land for agriculture.

Brazil with 30.3 millions of hectares and Argentina with 23.7 millions of hectares are among the countries with the highest percentage of transgenic crops (Rebossio, A., 2012;). Brazil has an average corn output of 3,46 ton/ha (2003-2007), and most of its production is transgenic production (IICA, 2008). On the other hand, Argentina, during the same number of years, recorded an average output of $6,81 \mathrm{ton} / \mathrm{ha}$ (IICA, 2008). In turn, for contrast, with conventional agriculture Nicaragua achieved an output of about de 1,46 ton/ha in 2007 (IICA, 2008). The USA remains by far the largest GMO producer in the world. Other world's leading GMO producers are India and China, as well as Paraguay, Uruguay and South Africa.

The previous information hints to the economic boost capacity that the application of GMO in agriculture has had, and it makes clearer the competitivity of agro products produced assisted by modern biotechnology (Bolívar Zapata, 2011). Argentina, for instances, reported gains of generated by their GM crops estimated on excess of 20 billion US dollars for a ten year period, 1996-2005.

Despite the economic benefits and efforts from biotechnology companies to promote GMO foods and agriculture, European remain wary and rate GMO foods as potentially unsafe and lacking real benefits (Livellara, S., 2005). This had negative effects on the US exports to the European Union (UE) which notably declined due to that (Santamarta, 2004). However, the UE has published a list of transgenic products that are accepted, such as MON 810 (Monsanto), Bt-176 maximizer corn (Ciba-Geigy) and T25 (AgrEvo) (Querci, M., Jermini, M. \& Van den Eede, G., 2007).

\section{Addressing the health and environmental risks of GMO}

The possible implications and risks of genetically modified food in human health is a matter of concern in many countries and it needs to be addressed (Bolivar Zapata, 2011). In regards to GM foods derived from GMO, most countries consider that specific assessments are necessary and a specific system has been established for the rigorous evaluation of GM organisms and GM foods relative to both human health and the environment. Similar rigorous evaluations are generally not performed for traditional foods and crops. Foods derived from GMO which are currently available on the market must have passed severe risk assessments and are not likely to present risks for human health. To date no effects on human health have been shown as a result of the consumption of such foods in the countries where they have been approved. Risk assessment protocols and practices based on the Codex principles and including post market monitoring generally form the basis for evaluating the safety of GM foods.

Organizations that oppose to GM technology keep constantly arguing about potential health risks of GM foods and crops. One recent publications by Gilles- 
Eric Séralin in Chemical Toxicology (September 2012) states that there is a direct correlation between the intake of transgenic products and the appearance of cancer and early death in rats. The Séralin study claimed that rats fed for two years with a form of GM corn modified to be resistant to a particular weed killer were several times more likely to develop lethal tumors and incur severe liver and kidney damage than those fed on standard wheat. However, in response to that publication the European Food Safety Authority (EFSA) has stated that there was no valid scientific evidence of such outcomes, and therefore, those health risk attributions were inadmissible (Mole, B. M., 2012). In an official statement the EFSA authorities pointed out that the Séralin study did not conform to standard study protocols and that the organization is "unable to regard the authors' conclusions as scientifically sound."

Regarding the health implications of the use of Genetically Modified Organisms, in 2003 the Food and Agriculture Organization of the United Nations (FAO) pointed out that this topic cannot be addressed in a general way but in a oneby-one manner. It is necessary to study their scope case-by-case to make complete and transparent evaluations. In addition, the FAO maintains that modern biotechnology duly developed could play an important role in agricultural food production and in other areas of human development, and that they could even contribute to food security. In addition, in 2005, the World Health Organization (WHO) stated that it was necessary to boost improvement in other highly important factors such as infrastructure and access to markets to reach an agricultural growth supported by technology and research.

Furthermore, since 2000, the US National Academies of Sciences along with other world academies have affirmed the need for GM technology and agriculture mainly to address the global deficiencies in nutrients, unemployment and as a whole, poverty. The world academies recommend that transgenic crop research and development is necessary to trigger the agro production stability, giving nutritional features to the consumer and reducing the environmental impact of intensive agriculture worldwide.

Due to the environmental concerns regarding the global use of transgenic crops and products, a call for regulation has been made, and this effort was strongly articulated at the Convention on Biological Diversity (CBD) celebrated on the Earth Summit in 1992 which in Article 19 foresaw the Biosafety Protocol of Cartagena. The Protocol was ratified by most of the United Nations member countries. It recommends an organization of the procedures for transfer, handling, and use of living modified organisms, products of biotechnology, which could affect the biological diversity of each country. Therefore, the protocol suggests the establishment of an Exchange Center on Biosafety in biotechnology which supports the exchange of scientific, technical, environmental, and legal information of Genetically Modified Organisms. In addition, it also suggests the establishment of a procedure for Advanced Informed Agreement (AIA) in which exporters should try to get the acceptance of the importers before their first introduction of GMO into other countries.

Furthermore, each delivery of staple crops in bulk containing GMO should be accompanied by appropriate documentation regarding the possible presence of these 
organisms, facilitating the precise identification of the transgenic stable products in international trade. Moreover, it is considered to be an addition to a safeguarding clause which states that both exporters and importers have to ensure that this agreement shall not alter any rights or obligations in accordance with the World Trade Organization (WTO) and other existing international agreements. Finally, this covers the direction needs in terms of modern biotechnology management, especially in developing countries (Carullo, J.C, 2002).

However, the implementation of the specifications in CBD leads to the detection of Genetically Modified Organisms and the organization of a regulatory framework for them. The introduction of genetically modified organisms (GMOs) in the world market, including crops, foods, and ingredients, legislation has been established worldwide to address the question of the use and labeling requirements on GMO plants, food and their derivatives.

\section{GMO detection methods}

With respect to the detection of GMO, there are various types of tests in use, including qualitative and quantitative tests. Protein and DNA-based methods, such as enzyme linked immune sorbent assay (ELISA), western blots, and qualitative and quantitative polymerase chain reaction PCR (Q-PCR). The lateral flow strips are related to the use of antibodies. On the other hand, the Polymerase Chain Reaction method (PCR) can be quantitative or qualitative (Bolívar-Zapata, 2011).

The lateral flow strip method is the only rapid, on-site method for GMO screening. In this method proteins are solubilized, and these react with the membrane antibody which is in the strips and finally the outcomes are read with the detection level of $1,33 \%$, which is suitable for this method. The reaction between the antibody located in the band and the protein isolated from the sample is seen when the band is dyed in pink color. To verify that the test was properly performed (validation), both the test band and the control band have to be seen. On the other hand, the appearance of just one band (the control band) shows a negative outcome, whereas the appearance of the two bands shows a positive outcome. Therefore, if neither of the bands appears, the test has no validation. (Gómez-Rodríguez, et. al, 2007)

Regarding the conventional PCR method, the Deoxyribonucleic Acid (DNA) is extracted and the Ribonucleic Acid (RNA) is discharged, and from this organic extraction, the section extracted is amplified by PCR, and finally the products amplified are detected by

agarose gel electrophoresis. In this procedure the concentration and integrity of the molecules extracted (proteins, nucleic acids, others) are verified through an agarose buffered matrix. This matrix works as a filter in which the molecules are split in an electric field according to their size and net charge. The nucleic acids separated in agarose gels can be seen through staining with fluorescent dyes and their concentrations determined by comparing them with known concentration patterns.

In addition, once the existence of detectable traces of GMO is verified through one or by both of these methods mentioned above (lateral flow strips or conventional PCR), the next step is to determine the amount of GMO present in the sample 
analyzed. For this step, real time PCR (RT-PCR) is generally preferred which differs from the conventional PCR in that it determines the reaction as it appears and it does not wait until its final point. Real time PCR is quantitative while conventional PCR is qualitative. In qualitative PCR a specific DNA fragment is detected whereas in quantitative PCR the target DNA sequence not only is detected but its amount is determined. Its principle is related to the emission of fluorescent light in each cycle of the reaction which is proportional to the amount of the products expressed after. Once the emission of this light is recorded in each cycle, the first notable increase is awaited to relate it to the initial amount of the sample deposited in the thermo cycler (Querci, M., Jermini, M., Van den Eede, G., 2007).

\section{GMO situation in Nicaragua}

With respect to the regulation framework consistent with the ratification of Cartagena Protocol, Nicaragua, particularly, has two important legislations in place: "Risk Prevention from Living Modified Organisms" and "Sustainable conservation and use of biological diversity".

In 2010, Law 705 was approved by the Nicaraguan National Assembly with the aim of regulating the activities carried out with these organisms so that they do not negatively affect human health, the environment, biological diversity or agricultural production. In this legislation, the products from Live Modified Organisms (LMO) which do not present detectable traces of transgenes are excluded; the LMO produced by mutagenesis; those obtained without recombinant DNA technology; and the raw materials obtained after industrial processing for animal feed (National Assembly of Nicaragua, 2010).

The Nicaraguan National Assembly also passed a law for sustainable conservation and use of biological diversity (September 2012). It regulates the conservation, preservation, recovery, and regeneration of wild and domesticated biological diversity, taking into account the species, breeds, and traditional local variety. In addition, it establishes mechanisms for the sustainable use of the component of biological diversity and the procedures for the access and use of genetic resources (Estrada, Y., 2012). The law bans the introduction of exotic and invading species, directly or indirectly, including natural, domesticated, or transgenic species that may endanger the existence of the native flora and fauna. In addition, the regulation states that for the introduction of new species, one has to comply mandatorily with the technical procedures and standards approved by the proper authority in accordance with the national legislation and international instruments that the country has ratified in terms of biodiversity.

Before the approval of these two laws described above, the only precedent of approval of GMO introduction was the authorization issued by the Government of Nicaragua to import yellow corn genetically modified approved for animal (poultry) feed only (see table 2). The events authorized were the following: 676, 678, 680, MS3, MS6, BT176, BT11, CT1507, MON863, MON810 (sterile pollen) as well as T14, T25, DLL25, these last few resistant to glufosinate. The permit was also for two events tolerant to glyphosate: GA21 and NK603. This was specified exclusively for process and animal feed (La Gaceta, 2005, See Table 2 for information on approved 
events and their features ${ }^{1}$. Yellow corn imports from the USA have continued without delays ever since.

The Ministry of Agriculture and Forestry (MAGFOR) works jointly with the Molecular Biology Center of Universidad Centroamericana (MBC-UCA), in accordance to the law, to detect Genetically Modified Organisms, especially in samples of grains imported into Nicaragua.

The Center uses a combination of immunological and PCR techniques to detect transgenic proteins or DNA. More recently the MBC-UCA has implemented the RT-PCR technique to detect GMO and to determine the exact percentage of GMO traces. RT-PCR is the gold technique and the crucial parameter determining the reliability of quantitative results, therefore it should be chosen as the primary criterion to evaluate the quality of the samples and to determine the specific events detected.

Since 2006 the Center has been collaborating with the governmental general directorate for Agricultural Protection and Plant Quarantine to screen crop imports and to help the government to coordinate and standardize regulations of GM crops in the country.

During 2012 (January through October), a total of one hundred and one samples were analyzed at the CBM-UCA. Ninety eight samples were rice grains, 2 corn samples, and 1 peanut. Some samples are analyzed using either immunological techniques or PCR, in some cases both methods are used depending on the authorities' requests. The Center also processed a number of samples submitted directly by the private sector.

The main conclusion from the processing of these samples is that Nicaraguan import companies are not introducing GMO via imports. The Plant Protection and Quarantine authorities are properly regulating the importation of plants and plant products.

The MBC-UCA has shown, however, that in some cases it is possible to detect small traces of GMO DNA probably from contaminating materials present in the containers used for transporting non-GMO crops and seeds. Accidental mixtures of GM and non-GM crops or adventitious GM presence can arise for a variety of reasons, including seed impurities, volunteers (plants that come up from seed left over from a previous crop), as well as from seeds left during storage and transport.

Despite the fact that Nicaragua has appropriate institutions and laws in place and with its capacity to detect the presence of GMO in food and crops, there is an urgent need for stronger screening and to monitor crop cultivation at the national level.

The United Nations Development Report (2001) titled "Making New Technologies Work for Development" recognized biotechnology as an important tool for the socio-economic growth of the developing world. Agro biotechnology already plays an important role in the development and growth of nations, improving productivity and generating important economic revenues. This is especially true in emerging countries such as India, China and Brazil. But biotechnology may also

1 Source: $h t t p: / / w w w . i s a a a . o r g / g m a p p r o v a l d a t a b a s e /$ event/default.asp? EventID $=87$ 
play an important role in less developed countries such as those in Central America where pest infestations, diseases and poor weather conditions significantly lower crop yields. Available GM crops as well as new local research could address these problems, where other breeding techniques have not been successful.

Although Nicaragua is not cultivating GM crops yet, it is already well equipped in terms of biosafety and biotech research starting point, especially considering the work of the MBC-UCA. Guidelines and directives issued by local authorities have set the necessary standards and will be of great support should the government were to promote biotechnology research to address the specific needs of Nicaraguan agricultural development. The government is called to take an even keener interest in the role of biotechnology in rural development. Its policies on biotechnology ought to be consistent with its overall nation-wide development policies, the main pillar of which is the structural struggle to combat poverty on a lasting basis.

Table 2. Summary of the 15 events approved for animal feed in Nicaragua.

\begin{tabular}{|c|c|c|c|c|}
\hline Event & $\begin{array}{c}\text { Gene } \\
\text { Introduced }\end{array}$ & Gene Source & Product & Function \\
\hline \multirow[b]{2}{*}{676} & pat & $\begin{array}{l}\text { Streptomyces } \\
\text { viridochromogenes strain Tu } \\
494\end{array}$ & $\begin{array}{l}\text { phosphinothricin } \\
\text { N-acetyltransferase } \\
\text { (PAT) enzyme }\end{array}$ & $\begin{array}{l}\text { eliminates herbicidal } \\
\text { activity of glufosinate } \\
\text { (phosphinothricin) } \\
\text { herbicides by } \\
\text { acetylation }\end{array}$ \\
\hline & dam & Escherichia coli & $\begin{array}{l}\text { DNA adenine } \\
\text { methylase enzyme }\end{array}$ & $\begin{array}{l}\text { confers male sterility } \\
\text { by interfering with } \\
\text { the production of } \\
\text { functional anthers } \\
\text { and pollen }\end{array}$ \\
\hline \multirow[b]{2}{*}{678} & pat & $\begin{array}{l}\text { Streptomyces } \\
\text { viridochromogenes strain Tu } \\
494\end{array}$ & $\begin{array}{l}\text { phosphinothricin } \\
\text { N-acetyltransferase } \\
\text { (PAT) enzyme }\end{array}$ & $\begin{array}{l}\text { eliminates herbicidal } \\
\text { activity of glufosinate } \\
\text { (phosphinothricin) } \\
\text { herbicides by } \\
\text { acetylation }\end{array}$ \\
\hline & dam & Escherichia coli & $\begin{array}{l}\text { DNA adenine } \\
\text { methylase enzyme }\end{array}$ & $\begin{array}{l}\text { confers male sterility } \\
\text { by interfering with } \\
\text { the production of } \\
\text { functional anthers } \\
\text { and pollen }\end{array}$ \\
\hline \multirow[b]{2}{*}{680} & pat & $\begin{array}{l}\text { Streptomyces } \\
\text { viridochromogenes strain Tu } \\
494\end{array}$ & $\begin{array}{l}\text { phosphinothricin } \\
\text { N-acetyltransferase } \\
\text { (PAT) enzyme }\end{array}$ & $\begin{array}{l}\text { eliminates herbicidal } \\
\text { activity of glufosinate } \\
\text { (phosphinothricin) } \\
\text { herbicides by } \\
\text { acetylation }\end{array}$ \\
\hline & dam & Escherichia coli & $\begin{array}{l}\text { DNA adenine } \\
\text { methylase enzyme }\end{array}$ & $\begin{array}{l}\text { confers male sterility } \\
\text { by interfering with } \\
\text { the production of } \\
\text { functional anthers } \\
\text { and pollen }\end{array}$ \\
\hline
\end{tabular}




\begin{tabular}{|c|c|c|c|c|}
\hline \multirow{3}{*}{ MS3 } & bar & Streptomyces hygroscopicus & $\begin{array}{l}\text { phosphinothricin } \\
\text { N-acetyltransferase } \\
\text { (PAT) enzyme }\end{array}$ & $\begin{array}{l}\text { eliminates herbicidal } \\
\text { activity of glufosinate } \\
\text { (phosphinothricin) } \\
\text { herbicides by } \\
\text { acetylation }\end{array}$ \\
\hline & barnase & Bacillus amyloliquefaciens & $\begin{array}{l}\text { barnase } \\
\text { ribonuclease } \\
\text { (RNAse) enzyme }\end{array}$ & $\begin{array}{l}\text { causes male sterility by } \\
\text { interfering with RNA } \\
\text { production in the } \\
\text { tapetum cells of the } \\
\text { anther }\end{array}$ \\
\hline & bla & Escherichia coli & $\begin{array}{l}\text { beta lactamase } \\
\text { enzyme }\end{array}$ & $\begin{array}{l}\text { detoxifies beta lactam } \\
\text { antibiotics such as } \\
\text { ampicillin }\end{array}$ \\
\hline \multirow{3}{*}{ MS6 } & bar & Streptomyces hygroscopicus & $\begin{array}{l}\text { phosphinothricin } \\
\text { N-acetyltransferase } \\
\text { (PAT) enzyme }\end{array}$ & $\begin{array}{l}\text { eliminates herbicidal } \\
\text { activity of glufosinate } \\
\text { (phosphinothricin) } \\
\text { herbicides by } \\
\text { acetylation }\end{array}$ \\
\hline & barnase & Bacillus amyloliquefaciens & $\begin{array}{l}\text { barnase } \\
\text { ribonuclease } \\
\text { (RNAse) enzyme }\end{array}$ & $\begin{array}{l}\text { causes male sterility by } \\
\text { interfering with RNA } \\
\text { production in the } \\
\text { tapetum cells of the } \\
\text { anther }\end{array}$ \\
\hline & bla & Escherichia coli & $\begin{array}{l}\text { beta lactamase } \\
\text { enzyme }\end{array}$ & $\begin{array}{l}\text { detoxifies beta lactam } \\
\text { antibiotics such as } \\
\text { ampicillin }\end{array}$ \\
\hline \multirow{3}{*}{ Bt 176} & cry1Ab & $\begin{array}{l}\text { Bacillus thuringiensissubsp. } \\
\text { kurstaki }\end{array}$ & $\begin{array}{l}\text { Cry1Ab delta- } \\
\text { endotoxin }\end{array}$ & \begin{tabular}{|l} 
confers resistance \\
to lepidopteran \\
insects by selectively \\
damaging their \\
midgut lining \\
\end{tabular} \\
\hline & bar & Streptomyces hygroscopicus & $\begin{array}{l}\text { phosphinothricin } \\
\text { N-acetyltransferase } \\
\text { (PAT) enzyme }\end{array}$ & $\begin{array}{l}\text { eliminates herbicidal } \\
\text { activity of glufosinate } \\
\text { (phosphinothricin) } \\
\text { herbicides by } \\
\text { acetylation } \\
\end{array}$ \\
\hline & bla & Escherichia coli & $\begin{array}{l}\text { beta lactamase } \\
\text { enzyme }\end{array}$ & $\begin{array}{l}\text { detoxifies beta lactam } \\
\text { antibiotics such as } \\
\text { ampicillin }\end{array}$ \\
\hline \multirow[b]{2}{*}{ Bt 11} & pat & $\begin{array}{l}\text { Streptomyces } \\
\text { viridochromogenes strain Tu } \\
494\end{array}$ & $\begin{array}{l}\text { phosphinothricin } \\
\text { N-acetyltransferase } \\
\text { (PAT) enzyme }\end{array}$ & $\begin{array}{l}\text { eliminates herbicidal } \\
\text { activity of glufosinate } \\
\text { (phosphinothricin) } \\
\text { herbicides by } \\
\text { acetylation } \\
\end{array}$ \\
\hline & $\operatorname{cry} 1 \mathrm{Ab}$ & $\begin{array}{l}\text { Bacillus thuringiensissubsp. } \\
\text { kurstaki }\end{array}$ & $\begin{array}{l}\text { Cry1Ab delta- } \\
\text { endotoxin }\end{array}$ & $\begin{array}{l}\text { confers resistance } \\
\text { to lepidopteran } \\
\text { insects by selectively } \\
\text { damaging their } \\
\text { midgut lining } \\
\end{array}$ \\
\hline
\end{tabular}




\begin{tabular}{|c|c|c|c|c|}
\hline & cry1Fa2 & $\begin{array}{l}\text { synthetic form of cry } 1 \mathrm{~F} \\
\text { gene derived from Bacillus } \\
\text { thuringiensis var. aizawai }\end{array}$ & $\begin{array}{l}\text { modified Cry1F } \\
\text { protein }\end{array}$ & $\begin{array}{l}\text { confers resistance } \\
\text { to lepidopteran } \\
\text { insects by selectively } \\
\text { damaging their } \\
\text { midgut lining }\end{array}$ \\
\hline CT1507 & pat & $\begin{array}{l}\text { Streptomyces } \\
\text { viridochromogenes strain } \\
\text { Tu } 494\end{array}$ & $\begin{array}{l}\text { phosphinothricin } \\
\text { N-acetyltransferase } \\
\text { (PAT) enzyme }\end{array}$ & $\begin{array}{l}\text { eliminates herbicidal } \\
\text { activity of glufosinate } \\
\text { (phosphinothricin) } \\
\text { herbicides by } \\
\text { acetylatio }\end{array}$ \\
\hline \multirow[b]{2}{*}{ MON863 } & cry3Bb1 & $\begin{array}{l}\text { Bacillus } \\
\text { thuringiensissubsp. } \\
\text { kumamotoensis }\end{array}$ & $\begin{array}{l}\text { Cry3Bb1 delta } \\
\text { endotoxin }\end{array}$ & $\begin{array}{l}\text { confers resistance } \\
\text { to coleopteran } \\
\text { insects particularly } \\
\text { corn rootworm by } \\
\text { selectively damaging } \\
\text { their midgut lining }\end{array}$ \\
\hline & nptII & $\begin{array}{l}\text { Escherichia coli Tn5 } \\
\text { transposon }\end{array}$ & $\begin{array}{l}\text { neomycin } \\
\text { phosphotransferase } \\
\text { II enzyme }\end{array}$ & $\begin{array}{l}\text { allows transformed } \\
\text { plants to metabolize } \\
\text { neomycin and } \\
\text { kanamycin antibiotics } \\
\text { during selection }\end{array}$ \\
\hline
\end{tabular}

\begin{tabular}{|c|c|c|c|c|}
\hline Event & $\begin{array}{c}\text { Gene } \\
\text { Introduced }\end{array}$ & Gene Source & Product & Function \\
\hline \multirow{4}{*}{ MON810 } & cry1Ab & $\begin{array}{l}\text { Bacillus } \\
\text { thuringiensissubsp. } \\
\text { kurstaki }\end{array}$ & $\begin{array}{l}\text { Cry1Ab delta- } \\
\text { endotoxin }\end{array}$ & $\begin{array}{l}\text { confers resistance to } \\
\text { lepidopteran insects by } \\
\text { selectively damaging their } \\
\text { midgut lining }\end{array}$ \\
\hline & goxv247 & $\begin{array}{l}\text { Ochrobactrum } \\
\text { anthropi strain } \\
\text { LBAA }\end{array}$ & glyphosate oxidase & $\begin{array}{l}\text { degrades the herbicide } \\
\text { glyphosate into } \\
\text { aminomethylphosphonic } \\
\text { acid (AMPA) and } \\
\text { glyoxylate }\end{array}$ \\
\hline & $\begin{array}{l}\text { cp4 epsps } \\
\text { (aroA:CP4) }\end{array}$ & $\begin{array}{l}\text { Agrobacterium } \\
\text { tumefaciensstrain } \\
\text { CP4 }\end{array}$ & $\begin{array}{l}\text { herbicide } \\
\text { tolerant form of } \\
\text { 5-enolpyruvulshikimate- } \\
\text { 3-phosphate synthase } \\
\text { (EPSPS) enzyme }\end{array}$ & $\begin{array}{l}\text { decreases binding } \\
\text { affinity for glyphosate } \\
\text { and confers increased } \\
\text { tolerance to glyphosate } \\
\text { herbicide }\end{array}$ \\
\hline & nptII & $\begin{array}{l}\text { Escherichia coli } \\
\text { Tn5 transposon }\end{array}$ & $\begin{array}{l}\text { neomycin } \\
\text { phosphotransferase II } \\
\text { enzyme }\end{array}$ & $\begin{array}{l}\text { allows transformed } \\
\text { plants to metabolize } \\
\text { neomycin and } \\
\text { kanamycin antibiotics } \\
\text { during selection }\end{array}$ \\
\hline
\end{tabular}




\begin{tabular}{|c|c|c|c|c|}
\hline \multirow[t]{2}{*}{ T14 } & pat (syn) & $\begin{array}{l}\text { synthetic form of } \\
\text { pat gene derived } \\
\text { fromStreptomyces } \\
\text { viridochromogenes } \\
\text { strain Tu } 494 \\
\end{array}$ & $\begin{array}{l}\text { phosphinothricin } \\
\text { N-acetyltransferase } \\
\text { (PAT) enzyme }\end{array}$ & $\begin{array}{l}\text { eliminates herbicidal } \\
\text { activity of glufosinate } \\
\text { (phosphinothricin) } \\
\text { herbicides by acetylation }\end{array}$ \\
\hline & bla & Escherichia coli & beta lactamase enzyme & $\begin{array}{l}\text { detoxifies beta lactam } \\
\text { antibiotics such as } \\
\text { ampicillin }\end{array}$ \\
\hline \multirow[t]{2}{*}{$\mathrm{T} 25$} & pat (syn) & $\begin{array}{l}\text { synthetic form of } \\
\text { pat gene derived } \\
\text { fromStreptomyces } \\
\text { viridochromogenes } \\
\text { strain Tu } 494 \\
\end{array}$ & $\begin{array}{l}\text { phosphinothricin } \\
\text { N-acetyltransferase } \\
\text { (PAT) enzyme }\end{array}$ & $\begin{array}{l}\text { eliminates herbicidal } \\
\text { activity of glufosinate } \\
\text { (phosphinothricin) } \\
\text { herbicides by acetylation }\end{array}$ \\
\hline & bla & Escherichia coli & beta lactamase enzyme & $\begin{array}{l}\text { detoxifies beta lactam } \\
\text { antibiotics such as } \\
\text { ampicillin }\end{array}$ \\
\hline \multirow[t]{2}{*}{ DLL25 } & bar & $\begin{array}{l}\text { Streptomyces } \\
\text { hygroscopicus }\end{array}$ & $\begin{array}{l}\text { phosphinothricin } \\
\text { N-acetyltransferase } \\
\text { (PAT) enzyme }\end{array}$ & $\begin{array}{l}\text { eliminates herbicidal } \\
\text { activity of glufosinate } \\
\text { (phosphinothricin) } \\
\text { herbicides by acetylation }\end{array}$ \\
\hline & bla & Escherichia coli & beta lactamase enzyme & $\begin{array}{l}\text { detoxifies beta lactam } \\
\text { antibiotics such as } \\
\text { ampicillin }\end{array}$ \\
\hline GA21 & mepsps & Zea mays & $\begin{array}{l}\text { modified } \\
\text { 5-enolpyruvylshikimate- } \\
\text { 3-phosphate synthase } \\
\text { (EPSPS) enzyme }\end{array}$ & $\begin{array}{l}\text { confers tolerance } \\
\text { to applications of } \\
\text { glyphosate-ammonium } \\
\text { based herbicides }\end{array}$ \\
\hline NK603 & $\begin{array}{l}\text { cp4 epsps } \\
\text { (aroA:CP4) }\end{array}$ & $\begin{array}{l}\text { Agrobacterium } \\
\text { tumefaciensstrain } \\
\text { CP4 }\end{array}$ & $\begin{array}{l}\text { herbicide } \\
\text { tolerant form of } \\
\text { 5-enolpyruvulshikimate- } \\
\text { 3-phosphate synthase } \\
\text { (EPSPS) enzyme }\end{array}$ & $\begin{array}{l}\text { decreases binding } \\
\text { affinity for glyphosate } \\
\text { and confers increased } \\
\text { tolerance to glyphosate } \\
\text { herbicide }\end{array}$ \\
\hline
\end{tabular}

\section{References}

BAYER. (2011). Annual Report 2011. Recuperado el 5 de Julio de 2012, de http:// www.annualreport2011.bayer.com/en/bayer-annual-report-2011.pdfx

Bocanegra, J. (2011). Introducción a los organismos genéticamente modificados: (OGM). Recuperado el 03 de Noviembre de 2012, de http://cera-gmc.org/docs/ colombia_2011/jose_bocanegra.pdf

Bolivar Zapata, F. (2011). Por un uso responsable de los organismos genéticamente modificados. (1ra ed.). México. Academia Mexicana de Ciencias, AC.

Carullo, J. C. (2003). Adecuación de los países al protocolo de Cartagena : ejemplo latinoamericano. Buenos Aires, Argentina: Instituto de Estudios Sociales de la Ciencia y la Tecnología. 
CEIBA Asociación para la Promoción y el Desarrollo de la Comunidad. (2003). Transgénicos iInvadiendo las mesas guatemaltecas? Recuperado el 02 de Noviembre de 2012, de http://www.fao.org/alc/legacy/iniciativa/cursos/Curso\%20 2004/doc1.pdf

DOW. (2011).Annual Report 2011. Recuperado el 5 de Julio de 2012, de http://www. dow.com/investors/pdfs/161-00769_2011_Annual_Report_Final.pdf

Estrada, Y. (2012). Aprueban Ley de Conservación y Utilización Sostenible de La Diversidad Biológica. Recuperado el 01 de Noviembre de 2012, de http://www.asamblea. gob.ni/84868/concluyen-aprobacion-de-ley-de-conservacion-y-utilizacionsostenible-de-la-diversidad-biologica/

Gómez Rodríguez, J., Oüdet, N. \& Huete Pérez, J. (2007). Monitoreo de arroz, soja y maiz comercializados en Nicaragua para detección de material transgénico. Recuperado el 26 de junio de 2012, de http://www.uca.edu.ni/encuentro/ images/stories/2012/pdf/78e/78e5a.pdf.

Iniciativa de Economía Alternativa y Solidaria. (2007). La producción y el comercio internacional del arroz. Recuperado el 03 de Julio de 2012, de Centro Nacional de Documentación e Información: http://cenida.una.edu.ni/relectronicos/ REE71I56p.pdf

Instituto Interamericano de Cooperación para la Agricultura (IICA). (2008). Indicadores socioeconómicos y sectoriales: agricultura y seguridad alimentaria. Recuperado el 01 de Noviembre de 2012, de http://repiica.iica.int/docs/ B0839E/B0839E.PDF

International Service for the Acquisition of Agri-Biotech Applications. (2012). GM Approval Database.Recuperado el 20 de Noviembre de 2012, de http://www. isaaa.org/gmapprovaldatabase/event/default.asp.

Livellara, S. (2005). Los transgénicos y su importancia en el futuro comercial de Argentina. Recuperado el 02 de noviembre de 2012, de http://www.biotech.bioetica. org/docta39.htm

MONSANTO. (2011).Financial Highlights 2011. Recuperado el 6 de Julio de 2012, de MONSANTO http://www.monsanto.com/investors/Pages/financialhighlights.aspxhttp://www.monsanto.com/investors/Pages/financialhighlights.aspx.

Organización de las Naciones Unidas para la Agricultura y la Alimentación (FAO). (2003). Los organismos modificados genéticamente, los consumidores, la inocuidad de los alimentos y el medio ambiente. Recuperado el 12 de julio de 2012, de http:// www.fao.org/docrep/003/x9602s/x9602s00.htm\#TopOfPage

Organización de las Naciones Unidas para la Educación, la Ciencia y la Cultura (UNESCO). (2000). OGM El campo de las incertidumbres: 5 fichas para comprender, anticipar, debatir. Recuperado el día 3 de Julio de 2012, de http:// unesdoc.unesco.org/images/0012/001246/124623s.pdf

Ortiz, R. (2010).Estado actual de la biotecnología moderna y su importancia en la seguridad alimentaria y el cambio climático: Perspectivas para América Latina y el Perú. Recuperado el 5 de Julio de 2012, de Slideshare: http://www.slideshare.net/ lacbiosafety/biotec-moderna-seguridad-alimentaria-y-cambio-climtico.

Programa de las Naciones Unidas para el Medio Ambiente (PNUMA). (2005). 
Evaluación de los Ecosistemas del Milenio: Informe de Sintesis-Borrador Final. Recuperado el 01 de Noviembre de 2012, de http://www.pnuma.org/ forodeministros/15-venezuela/ven09tre-EvaluaciondelosEcosistemasdelMile nio.pdf

Querci, M., Jermini, M., Van de Eede, G. (2007). Curso de formación sobre análisis de la presencia de organismos genéticamente modificados en muestras de alimentos. Luxemburgo: Oficina de Publicaciones Oficiales de las Comunidades Europeas.

Rebossio, A. (2012). Brasil y Argentina lideran el avance mundial de los transgénico. Recuperado el 02 de noviembre de 2012, de http://blogs.elpais.com/ecoamericano/2012/02/brasil-y-argentina-lideran-el-avance-mundial-de-lostransg\%C3\%A9nicos.html

Santamarta, J. (2004). Los transgénicos en el mundo: El qué, quién, cuánto, cuándo, dónde y por qué de los transgénicos. Recuperado el día 02 de julio de 2012, de http:// www.nodo50.org/worldwatch/ww/info.htm

SYGENTA. (2011).Full Year Results 2011. Recuperado el 5 de Julio de 2012, de http://www.syngenta.com/global/corporate/SiteCollectionDocuments/ pdf/presentations/media/20120208-en-Full-Year-Results-2011.pdf

National Academy of Sciencies (NAS). (2000). Transgenics Plants and World Agriculture. Recuperado el 20 de Noviembre de 2012, de http://books.nap. edu/openbook.php?record_id=9889\&page $=1$ 